\title{
Work Engagement: Trust and Respect to Engage your People
}

\author{
Yahia Salim Melhem* and Maen F. Al Qudah
}

Yarmouk University, Ministry of Education, Jordan; ymelhem@yu.edu.jo, m3n_qudah@hotmail.com

\begin{abstract}
Objectives: The purpose of this study is to examine the impact of interpersonal relationships (i.e. respect and felt trust) on work engagement among employees from the manufacturing sector in Jordan represented by a critical Oil and energy supply company; Al-Manaseer Group in Jordan. The study attempts to uncover the impact of procedural justice on employees' work engagement. Methods/Statistical Analysis: Data collected from 181 respondents were analyzed using SEM/Amos for data analysis, conformity factor analysis, path analysis, regressions and correlations. Findings: Results indicated that respect that employees receive from their managers and employees' felt trust positively affected their work engagement. Both mediated the relationship between procedural justice and work engagement and felt trust mediated the relationship between respect that employees receive from direct manager/supervisor and job engagement. The results also revealed that procedural justice has a positive effect on perceived respect from their direct manager/supervisor, withan also positive effect on employees' felt trust. Application/Improvements: Empirical study serves manufacturing organizations and hence its findings may provide a better understanding of the impact of respect, trust and justice on employees' work engagement. Thus, effective interpersonal relationships may further predict significant organizational consequences that require further research and analysis.
\end{abstract}

Keywords: Felt Trust, Procedural Justice, Respect, Work Engagement

\section{Introduction}

It is no longer viable to ignore the pervading influence of interpersonal relationships inorganizations. Good interpersonal relationships mean a positive environment and a supportive work climate that are necessary to produce better results ${ }^{1}$.

Positive interpersonal relationships facilitate many desirable outcomes such as organizational learning, cooperation, effectiveness, and employee loyalty ${ }^{2}$. Researchers have argued that interpersonal relationships predict proactive work behaviour and work engagement, in turn improving the organization's performance $\frac{3,4}{3}$.

Social relationships can positively enhance and smooth employees' performance at work. However, higher levels of job dissatisfaction, leave intention, and negative health outcomes occur in organizations with passive and negative interpersonal relationships $\frac{5,6}{6}$. Conversely, members in high-trust groups have higher levels of motivation than low-trust groups, leading to higher performance resulting from higher joint effort ${ }^{\underline{7}}$. There is immense research discussing interpersonal relationships in general and trust, respect, and engagement in particular. However, there seems a lack of studies covering an important area investigating the impact of interpersonal relationships represented by the respect that employees receive from their immediate managers, and employee felt trust and their impact of work engagement. This study will also contribute to the literature by studying the role of procedural justice on work engagement among employees in organizations.

This study will take place in Jordan at one major utility group in Jordan that is Manaseer Group. Jordan has a markedly different societal context for interpersonal

*Author for correspondence 
relationships from western countries and thus, offers an appropriate context for studying interpersonal relationships. Jordanian manufacturing companies expanded and developed in a way to bring more partnerships at the local and global levels with growth and expansion that require special attention to interpersonal relationships and their impact on work engagement which has a fundamental impact of organization's survival and competitiveness.

Moreover, this study, mainly, attempts to explore the impact of respect that employees receive from their managers on work engagement and to explore the impact of felt truston work engagement.

\section{Interpersonal Relationships}

Valued interpersonal relationships are expected to build a positive workplace environment where people feel comfortable, happy, motivated, and treated fairly. Such positive workplaces are required for organizations to achieve a high level of organizational and personal outcomes and performance ${ }^{8,9}$. Trust and respect are predicted to be significant factors that influence organizational outcomes ${ }^{10}$.

One popular definition is presented as the willingness of a party to be vulnerable to the actions of another party based on the expectation that the other will perform a particular action important to the trustor, irrespective of the ability to monitor or control that party ${ }^{11}$.

\section{Work Engagement}

Work engagement occurs when people choose to invest their full selves into role-related activities and become psychologically present when performing their roles $\underline{12}$. Also defined engagement "as a positive, fulfilling, workrelated state of mind that is characterized by vigour, dedication $\frac{13}{2}$, and absorption $\frac{12,14,15}{}$.

Another accepted definition of work engagement $\frac{16}{6}$ defined as a positive attitude held by employees characterized by a willingness and ability to help their company succeed, by providing sustainable discretional effort ${ }^{17-25}$. Hence, engaged employees are likely to be more satisfied and have more positive emotions to their job and their organization, willing to go above and beyond literal formal obligations, and characterized by their identification with goals and values of the organization $\underline{26-30}$.
Wech (2002) argued that the success of high-quality relationships is contingent on the level of mutual respect and trust. The foundation of employee engagement is respect, trust, and performance ${ }^{31}$. Hence, this study hypo thesises that respect and trust are essential for high-quality relationships between employees and their managers/ supervisors and that these quality relationships, in turn, predict employees' engagement.

\section{Respect}

While trust is very important and vital for better organizational outcomes and healthy interpersonal relationships, respect is also relevant and fundamental in our everyday life, because it is essential for human interaction and social relationships, it is important for building a moral community ${ }^{32,33}$. All people want to be respected in both private and work life ${ }^{34}$. If you ask people about the most important value in their work life, respect and how they are treated will take the highest priorities in the list $\frac{35}{5}$. Employees are more concerned with being treated with respect than recognition and appreciation ${ }^{36}$. $\mathrm{In}^{37}$ Argued that respect can be an attitude, principle, virtue, or attention. It can be demonstrated in forms of admiration, esteem, dignity, and care for another person ${ }^{38}$. In ${ }^{34}$ defined trust as an attitude towards others; where there is what justifies the attention, feeling of appreciation, and worth to that person. ${ }^{39}$ The most general, and the simplest definition of respect provided by ${ }^{40}$, they defined respect as a perceived worth according to one person by one or more others. ${ }^{41}$ suggested that respectful manager is the key for those looking at increasing profitability, increasing competitive edge, and engaging their workforce in fulfilling work $28,32,33,39,42-44$.

Respect can foster a sense of psychological safety, a sense of belonging and support members to feel secure ${ }^{45-47}$. Moreover, employees' commitment and engagement can be obtained by demonstrating respect by leaders ${ }^{36}$.

A study of nearly 20,000 employees from around the world revealed that respect was the most effective leader behavior on employees' work engagement and commitment $\frac{36}{36}$. Porath's study reported $56 \%$ of those employees who get respect from their leaders have better health and well-being, and most of them have reported greater engagement and satisfaction with their jobs. So, the current study attempts to fill the gap in the literature by investigating the impact of such relationships based on the assumption that people often feel that they are 
satisfied when they show concern and respect for them, in turn, they are more engaged in their jobs.

It can, therefore, be hypothesized that:

H1: Respect that subordinates receive from direct manager/supervisor has a positive effect on their level of job engagement in Manaseer group.

\section{Employees' Felt Trust}

Felt trust refers to subordinates' feeling of being trusted by their supervisors ${ }^{48}$. Felt trust seems to positively affect various work outcomes such as cooperative behaviors, job performance, organizational citizenship behaviors, and satisfaction, which in turn boost organizational performance ${ }^{49,50}$. Spreitzer and Mishra (1999) have conducted a study based on data collected from 517 top managers working in 43 firms. Their study indicated that trust in employees can be substituted for control, as well as trust in employees was positively related to involvement of employees in decision making which in turn enhances organizational performance $e^{48,50-52,53}$. Found that trust in the leader and the subordinate's feeling of being trusted motivate employee's cooperative behavior ${ }^{54}$. Also found that felt trust was related to employees' intrinsic motivation and experience of mastery ${ }^{\underline{49}}$. Reviewing the literature on felt trust one can observetheadequate emphasis on the impact of felt trust on different organizational outcomes including job performance, employee participation and satisfaction ${ }^{49}$. However, the relationship between felt trust and work engagement was not empirically tackled by previous studies, hence, this study fills this gap by focusing on the impact of felt trust on work engagement, since work engagement is expected to be influenced by the level of felt trust between managers and their employees stimulating vigour, dedication, and absorption among trusted employees $\frac{48,55}{}$. It can, therefore, be hypothesized the following:

H2: Subordinates' felt trust has a positive effect on their level of job engagement in Al Manaseer Group.

\section{Respect and Felt Trust}

Previous research has demonstrated that felt trust has a positive relationship with various work outcomes. For example $e^{53,56}$, suggested that subordinates' feelings of being trusted are associated with feeling appreciated and satisfied by their managers and supervisors. It also predicts that subordinates' cooperative behaviors may enhance organizational performance $e^{50,52,57}$. Subordinates then, aremore willing to make closer mutual trust relationship, which promotes the level of subordinates' work engagement and involvement $\frac{58,59}{\text {. All this might }}$ contribute to subordinates' perception of felt trust and related somewhat to the perception of respect $\frac{58,60}{} \operatorname{In}^{59,61}$ have argued that fairness might also be a way of showing that the subordinate is trusted. Although extensive research has been carried out on both respect and trust in organization, no study has so far examined the potential relationship between respect that employees receive from direct managers or supervisors and their felt trust. In line with this rationale, the current study hypothesises that there is a strong relationship between respect and felt trust, and in turn, the following hypotheses are derived:

H3: Respect that subordinates receive from their direct manager/supervisor has a positive effect on their level of felt trust.

H4: Employees felt trust mediate the relationship between respect that employees receive from direct manager/ supervisor and job engagement.

\section{Organizational Justice}

Organization justice refers to the study of fairness within organizations ${ }^{62,63}$. Reported a positive relationship between organizational justice and several organizational outcomes such as organizational commitment, job satisfaction, performance, and citizenship behaviors ${ }^{62,64,65}$. Procedural justice that is more context-relevant can be defined as the employees' perception toward fairness of organizational policies, procedures and the processes used by decision makers ${ }^{62,66,67}$. For example, ${ }^{68}$ postulates that justice is an important antecedent to employee engagement. Based on a sample of 208 hotel employees and their managers working in North Cyprus, ${ }^{69}$ concluded that organizational justice has a strong effect on both organizational citizenship behavior and job satisfaction. Also, ${ }^{70}$ argued that all dimensions of organizational justice - distributive, procedural and interactional justice - have a significant and positive influence on commitment. In this study, however, the attempt is to explore the impact of procedural justice on work engagement. 


\section{Procedural Justice and Interpersonal Respect}

Hypothesize that all types of justice including the procedural type of justice provide strong signals of worker's worth and respect $\frac{39}{}$. It has been found that perceived procedural justice is strongly influenced by interpersonal treatment and the way individuals are treated during the implementation of the procedures $\frac{61,71}{}$. According to group-value model ${ }^{33}$, when individuals perceive fair treatment by people, group and organizations, they may feel that they are respected and welcomed within these group and organizations, which may enhance their feelings of self-worth ${ }^{33}$.

Thus, it can be hypothesized the following:

H5: Procedural justice has a positive effect on the respect that employees receive from their direct manager/supervisor in Manaseer Group.

H6: Respect that employees receive from their direct manager/supervisor mediate the relationship between procedural justice and job engagement.

\section{Organizational Justice and Employees' Felt Trust}

Felt trust has received considerable and increasing attention in trust literature $\frac{48,50,52,59,72}{}$. Most researchers indicated that felt trust has a positive relationship with various work outcomes such as cooperative behaviors, job performance, organizational citizenship behaviors, and satisfaction, which in turn boost organizational performance. $\operatorname{In}^{50}$ suggested the role of employees' feeling of being trusted is highly significant and vital for employees than most types of incentives and appreciations. ${ }^{53}$ Argued that fairness is a manager's tool to show that the subordinate is trusted. ${ }^{49}$ Argued that felt trust is positively associated with workplace productivity and engagement. Accordingly, the current study expects a positive relationship between procedural justice and employees' felt trust. Therefore, it can be hypothesized the following:

H7: procedural justice has a positive effect on employees' felt trust.

H8: Employees' felt trust mediates the relationship between procedural justice and job engagement.

\section{Method}

\subsection{Sample}

A questionnaire was administered and distributed to the employees of Almanseer Group in Jordan. This Group is operating across the region, involved in oil, energy, and manufacturing. The original sample consists of 350 employees, and data were obtained from 181 with a response rate of $52 \%$. The sample consists of employees from 25 to 55 yrs of age. Majority of the sample were male $148(82 \%) .95 \%$ of the sample with a diploma or bachelor's degree.

$90 \%$ were office employees and $10 \%$ were supervisors. Majority of employees have worked in the company from 3 years to 15 years.

\subsection{Measures}

The questionnaire consists of five sections, the first was related to the demographics (gender; age; education; employment duration and job position). The other four sections of the instrument involved items related to respect from the immediate manager (12 items), felt trust (6 items), procedural justice (6 items) and job engagement (9 items). 5-point Likert scale was used for all measures.

Respect from Immediate Manager/supervisor was measured by 12 -item scale adopted from Respectful Leadership Scale developed by ${ }^{34}$. A sample item is "My immediate manager trusts my ability to independently and self-reliantly perform well". Cronbach alpha coefficients for these items were 0.89 .

Felt trust was measured by 6 items from ${ }^{\frac{73}{3}}$ with minor modification to fit the context. Example item includes "Given my track record, my immediate manager sees no reason to doubt my competence and preparation for the job". Cronbach alpha coefficients for these items were 0.88 .

Procedural Justice was measured by 6 items developed by ${ }^{66}$. The items were modified to suit the current research context. Example items include "I have influence over the (outcomes) arrived at by my organizational procedures"; "My manager does not make improper remark or comments". Reliability measures $=0.85$ and 0.91 respectively.

Job Engagement was measured by shortened version (UWES-9) developed by ${ }^{13}$. Reliability $=0.92$.

Table (1) presents the means, standard deviations, correlations, and reliabilities for all variables. The 
Table 1. Means, standard deviations, correlations, and reliabilities for study variables

\begin{tabular}{|llc|c|cc|c|c|}
\hline & Variables & $\mathbf{M}$ & SD & $\mathbf{1}$ & $\mathbf{2}$ & $\mathbf{3}$ & $\mathbf{4}$ \\
\hline $\mathbf{1}$ & Respect & 1.727 & .512 & $\mathbf{( 0 . 8 9 3 )}$ & & & \\
\hline $\mathbf{2}$ & Felt Trust & 1.919 & .624 & $.675^{* *}$ & $\mathbf{( 0 . 9 1 1 )}$ & & \\
\hline $\begin{array}{l}\text { 3 } \\
\text { Procedural } \\
\text { Justice }\end{array}$ & 2.376 & .731 & $.483^{* *}$ & $.588^{* *}$ & $\mathbf{( 0 . 8 5 3 )}$ & \\
\hline $\mathbf{4}$ & Job Engagement & 1.946 & .761 & $.440^{* *}$ & $.557^{* *}$ & $.611^{* *}$ & $\mathbf{( 0 . 9 1 6 )}$ \\
\hline
\end{tabular}

**. Correlation is significant at the 0.01 level, $\mathrm{N}=181$. Reliabilities are in parentheses.

reliabilities of all variables were acceptable for research purposes and ranged from 0.85 to 0.92 . All variables were positively correlated to each other at $\mathrm{p}<0.01$.

\section{Data Analysis}

In this study, data were analyzed using Anderson and Gerbing's (1988) two-step approach whereby the estimation of the confirmatory measurement model precedes the estimation of the structural model. The theoretical model was tested using SEM/AMOS analysis. All study variables were subjected to a series of exploratory factor analysis (EFA) ${ }^{74}$. During the EFA process, some of the items had loadings below 0.50 , cross-loaded, or were not clearly identified with any of the study factors.

Therefore, four items were removed from the respect measure (R1, R2, R3, R4), three items from the felt trust (FT1, FT2, FT4) one item from the procedural justice (J6), and one item from work engagement (En1). All removed items during the EFA are shown in Table (2).

Table 2. Removed items during EFA

\begin{tabular}{|l|l|l|}
\hline Items & Factor & Reason for Removing \\
\hline R1 & Respect & Low loading \\
\hline R2 & Respect & Not Identified to any factors \\
\hline R3 & Respect & Low loading \\
\hline R4 & Respect & Cross loading \\
\hline FT1 & Felt Trust & Cross loading \\
\hline FT2 & Felt Trust & Cross loading \\
\hline FT4 & Felt Trust & Low loading \\
\hline J6 & Procedural Justice & Not Identified to any factors \\
\hline En1 & work Engagement & Cross loading \\
\hline
\end{tabular}

Results demonstrated seven-factor solution with eigenvalues greater than 1.0 and loading cumulative of $68.1 \%$ of the variance. Table (3) presents the results of exploratory factor analysis (EFA) for all study factors with good reliabilities.
Table 3. The exploratory factor analysis (EFA) for all study factors

\begin{tabular}{|l|c|c|c|c|}
\hline \multirow{2}{*}{ Items } & \multicolumn{4}{|c|}{ Factor } \\
\cline { 2 - 5 } & Engage & Respect & Felt Trust & P. Justice \\
\hline R5 & & .539 & & \\
\hline R6 & & .673 & & \\
\hline R7 & & .646 & & \\
\hline R9 & & .753 & & \\
\hline R10 & & .742 & & \\
\hline R11 & & .772 & & \\
\hline R12 & & .630 & & .715 \\
\hline FT3 & & & .532 & \\
\hline FT5 & & & .550 & \\
\hline FT6 & & & .890 & \\
\hline FT7 & & & .912 & \\
\hline FT8 & & & .748 & \\
\hline FT9 & & & .904 & \\
\hline FT10 & & & .454 & \\
\hline J1 & & & & \\
\hline J2 & & & & \\
\hline J3 & & & & \\
\hline J4 & & & & \\
\hline J5 & & & & \\
\hline En2 & .763 & & & \\
\hline En3 & .819 & & & \\
\hline En4 & .793 & & & \\
\hline En5 & .877 & & & \\
\hline En6 & .775 & & & \\
\hline En7 & .790 & & & \\
\hline En9 & .629 & & & \\
\hline
\end{tabular}

Notes: Extraction Method: Maximum Likelihood; Rotation Method: Promax with Kaiser Normalization; Kaiser-MeyerOlkin Measure of Sampling Adequacy value is 0.920; Bartlett's test of Sphericity: sig. 0.000 and Reliabilities are in parentheses; Loadings under 0.50 are not presented. 
All variables were then subjected to CFA with AMOS to assess the quality of the measurement model using convergent and discriminant validity for the key variables prior to hypothesis testing. Following ${ }^{75}$, the examination of multiple model fit indices was conducted. Model fitness was assessed usingthe following fit indices: CMIN/DF measure; the comparative fit index (CFI); Bollen's Incremental Fit Index (IFI); TLI = Tucker-Lewis Index; SRMR = standardized root mean squared residual; RMSEA $=$ root mean squared error of approximation and PClose measure. The fit indices for the initial model fit indicated that the model needed to be re-specified to fit better with the sample data. To improve model fit, 1 item was removed due to low loading, 2 items were sequentially removed due to the significant value of residual covariance exceeding a value of 2.0 and significantly decrease the model fit. Finally, 3 items were removed to achieve adequate convergent and discriminant validity, as well as reliability (Table 3). All removed items during confirmatory factor analyses (CFA) are shown in Table (4).

Table 4. Removed Items during CFA

\begin{tabular}{|l|l|l|}
\hline Items & \multicolumn{1}{|c|}{ Factor } & \multicolumn{1}{|c|}{ Reason for Removing } \\
\hline R7 & Respect & $\begin{array}{l}\text { Residual covariance } \\
\text { exceeding a value of } 2.0\end{array}$ \\
\hline R8 & Respect & $\begin{array}{l}\text { Convergent and } \\
\text { discriminant validity }\end{array}$ \\
\hline FT10 & Felt Trust & $\begin{array}{l}\text { Residual covariance } \\
\text { exceeding a value of } 2.0\end{array}$ \\
\hline J4 & ProceduralJustice & $\begin{array}{l}\text { Convergent and } \\
\text { discriminant validity }\end{array}$ \\
\hline En2 & Job Engagement & $\begin{array}{l}\text { Convergent and } \\
\text { discriminant validity }\end{array}$ \\
\hline
\end{tabular}

After successive refinements, the obtained adjusted model can be seen in Figure (1) with all items loaded quite well onto the factors. The result of the Confirmatory Factor Analysis (CFA) model fit indices indicated good model fit, the values for indices were $C M I N / D F=1.699$; $\mathrm{CFI}=0.938 ;$ RMSEA $=0.062 ; \mathrm{SRMR}=0.058 ;$ PClose $=0.041$; $\mathrm{TLI}=0.928$ and $\mathrm{IFI}=0.939$. According to cutoff criteria for fit indexes for ${ }^{75}$, these values represented a good decent model fit. Table (5) show the Estimations of the model fit measures.

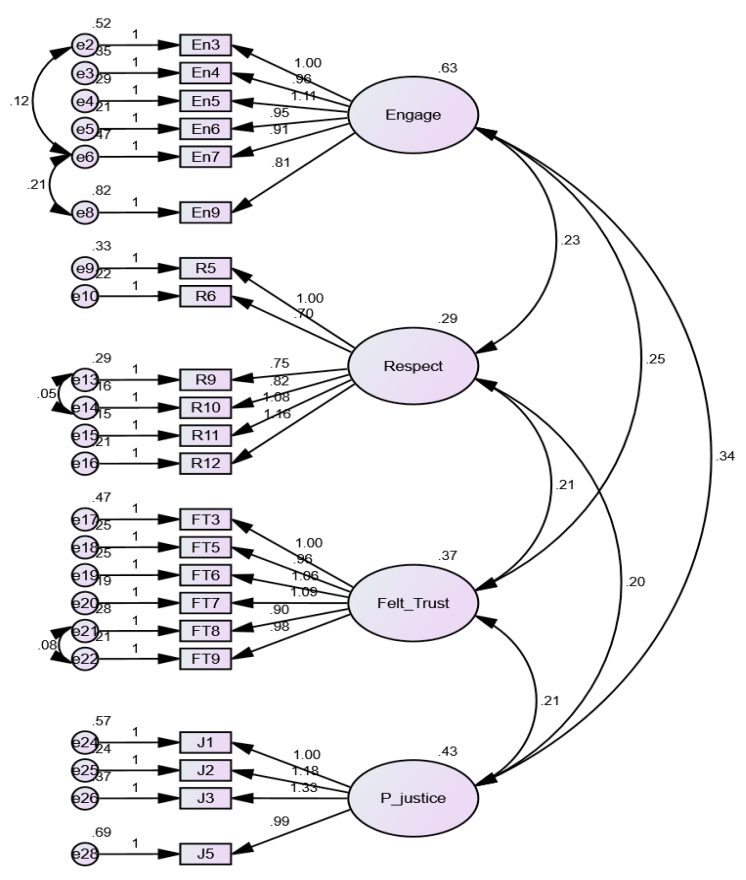

Figure 1. Confirmatory Factor Analysis (CFA).

Table 5. Estimationof the model fit measures

\begin{tabular}{|c|c|}
\hline Measure & Estimate \\
\hline CMIN & 358.160 \\
\hline DF & 199.00 \\
\hline CMIN/DF & 1.699 \\
\hline CFI & 0.938 \\
\hline TLI & 0.928 \\
\hline IFI & 0.939 \\
\hline PClose & 0.041 \\
\hline SRMR & 0.058 \\
\hline RMSEA & 0.062 \\
\hline
\end{tabular}

\section{Validity and Reliability of the Measurement Model}

To ensure the validity of the measurement model, convergent and discriminant validity should be examined ${ }^{76-77}$. All values were as evidenced by (convergent is AVE above 0.5, discriminate is squares root of AVE greater than correlations) and reliability evidenced by (CR value above 0.700 ). This value is in acceptable range $\mathrm{e}^{75}$. Table (6) represent model validity measures. 
Table 6. Model Validity Measures

\begin{tabular}{|l|c|c|l|l|l|l|l|l|}
\hline & CR & AVE & MSV & $\operatorname{MaxR(H)}$ & Engage & Respect & Felt_Trust & P_Justice \\
\hline Engage & 0.891 & 0.580 & 0.421 & 0.907 & $\mathbf{0 . 7 6 2}$ & & & \\
\hline Respect & 0.862 & 0.514 & 0.409 & 0.878 & $0.544 * * *$ & $\mathbf{0 . 7 1 7}$ & & \\
\hline Felt_Trust & 0.893 & 0.583 & 0.409 & 0.900 & $0.528 * * *$ & $\mathbf{0 . 6 4 0} * * *$ & $\mathbf{0 . 7 6 4}$ & \\
\hline P Justice & 0.826 & 0.547 & 0.421 & 0.854 & $0.649 * * *$ & $0.571 * * *$ & $0.518^{* * *}$ & $\mathbf{0 . 7 4 0}$ \\
\hline
\end{tabular}

Notes: $\mathrm{CR}=$ Composite Reliability; AVE = Average Variance Extracted; MSV =Maximum Shared Variance; The square root of the AVEin bold; Engage= Job Engagement; Respect = Respect From Manager; Felt Trust $=$ Felt Trust From Manager; P_Justice $=$ Procedural Justice. Significance of Correlations: ${ }^{*} \mathbf{p}<0.050 ; * * \mathbf{p}<0.010 ; * * * \mathbf{p}<0.001$

\begin{tabular}{|c|c|c|c|c|c|c|c|c|}
\hline Measure & CMIN & DF & CMIN/DF & CFI & TLI & IFI & SRMR & RMSEA \\
\hline Estimate & 370.282 & 201.00 & 1.842 & 0.925 & 0.913 & 0.926 & 0.075 & 0.068 \\
\hline
\end{tabular}

\section{Results and Hypotheses}

After obtaining the adjusted model, the structural model has been drawn, and the estimation by maximum likelihood method implemented by using Amos Program version 24. Figure (2) displays the standardized parameter estimates for the structural model. The model fit indices provide a good model fit for the the structural model. The values for indices were $\mathrm{CMIN} / \mathrm{DF}=1.842$; $\mathrm{CFI}=0.925$; $\mathrm{SRMR}=0.075$; RMSEA $=0.068$; TLI $=0.913$ and IFI $=$ 0.926 . This represented a good model fit $\frac{75}{}$, showing that the proposed research model fits the data reasonably. All estimated paths in the model were significant. Therefore, all hypotheses are supported. The standardized regression weights of the output and result of the hypotheses testing are presented in appendix (1).

\section{Discussion}

The results in this study support the assumption that positive interpersonal relationships significantly and positively impact work engagement. This result confirms the one presented by ${ }^{\frac{78}{6}}$, Suggesting that positive relationships between employees and their leaders positively influence employees' loyalty, commitment, and work engagement. Results in Table (5 and 6) indicated the positive impact of felt trust and respect on work engagement. Results in this study illustrated that subordinates' feeling that they are trusted by their direct managers/supervisors has a significant positive effect on their level of job engagement. The results also indicated that felt trust mediates the relationship between respect

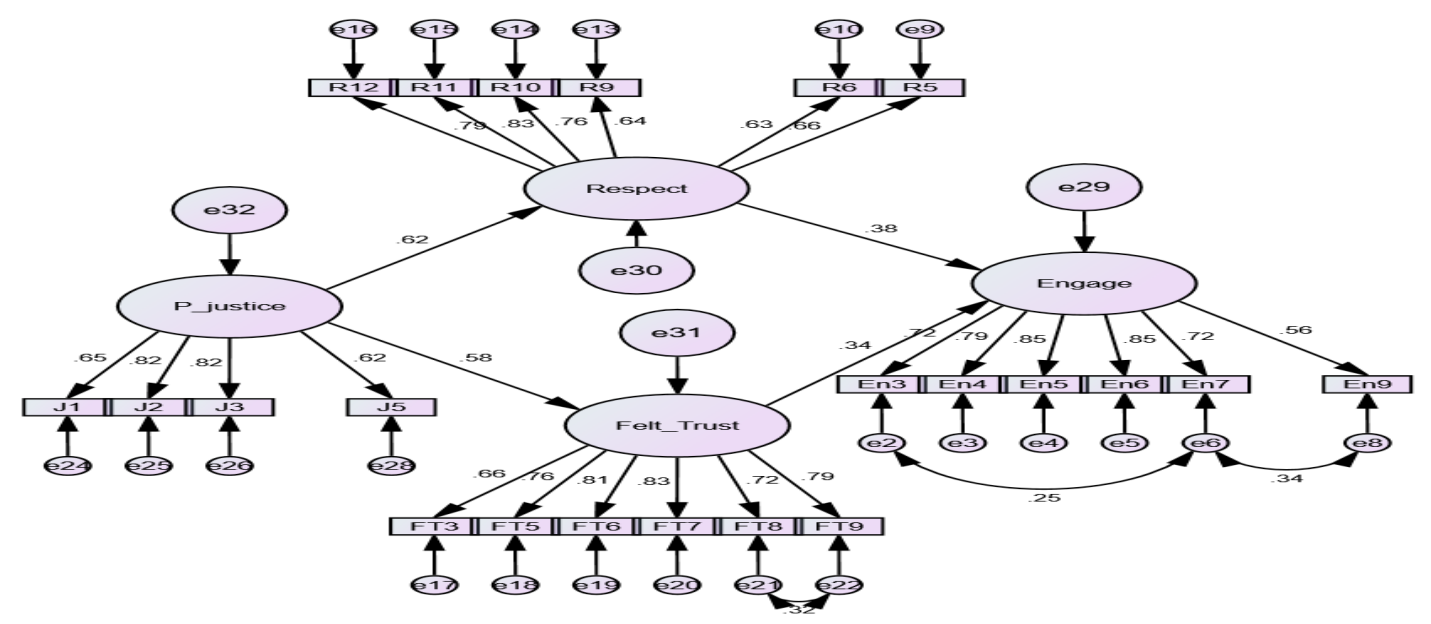

Figure 2. The structural model. 
Appendix (1) Testing the Hypotheses

\begin{tabular}{|l|l|l|l|l|}
\hline \multicolumn{2}{|c|}{ Hypothesis } & $(\boldsymbol{\beta}$ value $)$ & (P value) & Supported/ Not \\
\hline $\mathbf{H 1}$ & $\begin{array}{l}\text { Respect that subordinates receive from direct manager/supervisor has } \\
\text { positive effect on their level of job engagement in Al Manaseer group. }\end{array}$ & $\mathbf{0 . 3 6 6}$ & $* * *$ & Supported \\
\hline $\mathbf{H} \mathbf{2}$ & $\begin{array}{l}\text { Subordinates' felt trust has positive effect on their level of job engagement in } \\
\text { Al Manaseer Group. }\end{array}$ & $\mathbf{0 . 3 1 1}$ & $\mathbf{0 . 0 0 2} * *$ & Supported \\
\hline $\mathbf{H 3}$ & $\begin{array}{l}\text { Respect that subordinates receive from their direct manager/supervisor has } \\
\text { positive effect on their level of felt trust in Al Manaseer group. }\end{array}$ & $\mathbf{0 . 4 8 6}$ & $* * *$ & Supported \\
\hline $\mathbf{H 4}$ & $\begin{array}{l}\text { Employees felt trust mediate the relationship between respect that employees } \\
\text { receive from direct manager/supervisor and job engagement in Al Manaseer } \\
\text { group. }\end{array}$ & $\mathbf{0 . 2 2 5}$ & $\mathbf{0 . 0 0 7 * *}$ & Supported \\
\hline $\mathbf{H 5}$ & $\begin{array}{l}\text { Procedural justice has positive effect on respect that employees receive from } \\
\text { their direct manager/supervisor in Al Manaseer Group. }\end{array}$ & $\mathbf{0 . 5 8 3}$ & $* * *$ & Supported \\
\hline $\mathbf{H 6}$ & $\begin{array}{l}\text { Respect that employees receive from their direct manager/supervisor } \\
\text { mediate the relationship between procedural justice and job engagement. }\end{array}$ & $\mathbf{0 . 2 5 1}$ & $\mathbf{0 . 0 1} * *$ & Supported \\
\hline $\mathbf{H 7}$ & $\begin{array}{l}\text { Procedural justice has positive effect on employees' felt trust in Manaseer } \\
\text { Group. }\end{array}$ & $\mathbf{0 . 2 4 8}$ & $\mathbf{0 . 0 0 9} * *$ & Supported \\
\hline $\mathbf{H 8}$ & $\begin{array}{l}\text { Employees' felt trust mediate the relationship between procedural justice and } \\
\text { job engagement. }\end{array}$ & $\mathbf{0 . 0 9 1}$ & $\mathbf{0 . 4 2 *}$ & Supported \\
\hline
\end{tabular}

$*$ is significant at $\mathbf{p}<.10 * *$ is significant at $\mathbf{p}<.01 * * *$ is significant $\mathbf{p}<0.001$

that employees receive from direct manager/supervisor and their level of job engagement.

Additionally, the findings reveal agreement with $\underline{49}$ who suggested that employees who feel trusted positively affect workplace productivity and engagement.

Nevertheless, there is a lack of empirical research investigating the effect of felt trust on job engagement. However, this finding to some extent is in line with ${ }^{77}$ who found that felt trust is positively associated with task performance and interpersonal facilitation ${ }^{48,53}$.

Results also revealed that respect that subordinates receive from direct manager/supervisor positively affects the subordinates' level of trust in manager, and that respect had an indirect effect on subordinates' level of job engagement through subordinates' affect-based trust in manager, and through subordinates' feeling that they are being trusted. When subordinates feel that they are respected by their direct managers or supervisors, they are more willing to trust those managers, in turn, they become more engaged in their jobs. These results are in lines with $\frac{79,80}{}$ who concluded that managers are perceived as trustworthy when subordinates feel that those managers treat them.

Moreover, organizational justice demonstrated a significant positive effect on the respect that subordinates receive from their direct managers/supervisors ${ }^{39,61,81}$.
${ }^{66}$ Argued that treatment with respect is an input for fair judgment. Consistent with our findings in this study Bies \& Moag (1986) suggested that respect for people and civility are part of an individual's perception of procedures to be fair or not.

Finally, the current study found that procedural justice has a significant positive effect on subordinate's felt trust and that procedural justice has a positive impact on subordinates' level of work engagement through subordinates' feeling being trusted ${ }^{63,82}$. Subordinates' feeling of fairness lead to a higher level of trust in supervisors $\frac{83-85}{2} . \frac{50,53,59}{}$ Suggested that fair treatment makes subordinates feel that they are being trusted, which in turn promote their cooperative behaviors, job performance, organizational citizenship behaviors, satisfaction, and ultimately enhancing engagement to their job.

\section{Limitations and Future Research}

Measures used in this study were all self-reported, which raises the question of whether common method biases may have influenced our results ${ }^{86}$. However, for future research to obtain more robust findings and to enhance the generalizability of the findings, result should be 
cross-validated using additional methodologies and examining a broader range of participants from different organizations and countries. However, this limitation can be encountered by a mixed-methods approach with qualitative and quantitative methods. Moreover, experimental or longitudinal designs can be utilized in future research to test the suggested relationships further. Future researchers can also overcome issues inherent to the longitudinal design by selecting a stablesetting and limiting participant attrition ${ }^{39,87}$. Finally, Further research in felt trust and affect-based trust is recommended due to prior research evidence that employees' felt trust is positively associated with various organizations and individuals' outcomes such as task performance, organizational citizenship behaviors, job satisfaction and employee's cooperative behavior $\frac{48,53,88}{}$.

\section{Implications}

This study offers several theoretical implications and suggests several opportunities for more in-depth research regarding the study constructs. The first important implication of the current study is the need for researchers to consider referents of trust other than supervisors. Although trust in subordinates and their felt trust are very important for workplace relationships and associated with many organizational outcomes such as job engagement. Almost all previous studies have examined unidirectional trust with focusing on trust in supervisors ${ }^{89}$, and very little research has examined trust in downward relationships. So, the findings of the current study suggest that trust literature is vital for researchers to examine the associations between trust in downward relationships and employee workout comes.

The second theoretical implication is in emphasizing the importance of examining felt trust and its consequent associations with respect and work engagement. ${ }^{87}$ Found that felt trust is vital for predicting outcomes of commitment, job satisfaction, and positive attitudes among employees. Procedural justice also revealed significant importance and impact on work engagement in Al-Manaseer group in Jordan. Finally, due to lack of trust and respect studies in the Jordan, this study makes significant contributes by encouraging managers in Al-Manaseer group and other similar energy companies to consider the significance of felt trust, respect, justice and value their impact on work engagement and other work-related consequences.

\section{Conclusion}

Due to the importance of maintaining positive relationships increating trust and respect-culture leading to work engagement, this effort suggests several recommendations for Jordanian oil and energy organizations, specially Al-Manaseer Group to improve levels of work engagement via positive interpersonal climate characterized by trust, respect and justice. Overall, work engagement seems very important antecedent to enhanced quality of work, performance, and productivity. Given such positive outcomes of work engagement, Jordan manufacturing companies like Al-Manaseer Group need to provide the necessary antecedents conducive for work engagement including positive interpersonal climate with felt trust, respect, and procedural justice.

\section{References}

1. Motivation and organizational climate. Available from: https://books.google.co.in/books/about/Motivation_and_ Organizational_Climate.html?id=FVevAAAAIAAJ. Date accessed: 1968.

2. Reis HT, Gable SL. Toward a positive psychology of relationships. Keyes CLM, Haidt J (Eds.), Flourishing: Positive psychology and the life well-lived. 2003; p. 129-59. https://doi.org/10.1037/10594-006 PMid:12490305

3. Interpersonal relationships at work: An examination of dispositional influences and organizational citizenship behavior. Available from: https://kb.osu.edu/ handle/1811/48334. Date accessed: 2011.

4. Warshawsky NE, Havens DS, Knafl G. The influence of interpersonal relationships on nurse managers' work engagement and proactive work behavior. The Journal of nursing administration. 2012; 42(9):418-20. https://doi. org/10.1097/NNA.0b013e3182668129 PMid:22922751 PMCid:PMC4071766

5. Bowling NA, Beehr TA. Workplace harassment from the victim's perspective: A theoretical model and meta-analysis. Journal of Applied Psychology.2006;91(5):998-1012.https:// doi.org/10.1037/0021-9010.91.5.998 PMid:16953764

6. Cortina LM, Magley VJ. Raising voice, risking retaliation: Events following interpersonal mistreatment in the workplace. Journal of Occupational Health Psychology. 2003; 8(4):247-65. https://doi.org/10.1037/10768998.8.4.247 PMid:14570522

7. Dirks KT. The effects of interpersonal trust on work group performance. Journal of Applied Psychology. 1999; 84(3):445-510. https://doi.org/10.1037//00219010.84.3.445 PMid:10380424 
8. Ragins BR, Dutton JE. Positive Relationships at Work: An Introduction and Invitation. Exploring Positive Relationships at Work: Building a Theoretical and Research Foundation. 2007; p. 29-45.

9. Martinez-Corts I, Boz M, Medina FJ. Coping with Interpersonal Conflict at Work in Small Business: The Moderating Role of Supervisor and Co-Worker Support. Revista de Psicología del Trabajo y de las Organizaciones. 2011; 27(2):117-29. https://doi.org/10.5093/tr2011v27n2a4

10. Trust: A Sociological Theory. Available from: https://books. google.co.in/books/about/Trust.html?id=ZrwvSrK5I8AC\& redir_esc=y. Date accessed: 1999.

11. Mayer RC, Davis JH, Schoorman FD. An Integrative Model of Organizational Trust. Academy of Management Review. 1995; 20(3):709-34. https://doi.org/10.5465/ amr.1995.9508080335

12. Kahn WA. Psychological conditions of personal engagement and disengagement at work. Academy of Management Journal. 1990;33(4):692-724. https://doi.org/10.5465/256287

13. Schaufeli WB, Salanova M, Gonzalez-Roma V, et al. The measurement of engagement and burnout: a two sample confirmatory factor analytic approach. Journal of Happiness Studies. 2002; 3:71-92. https://doi.org/10.1023/ A:1015630930326

14. Bakker AB, Demerouti E. Towards a model of work engagement. Career Development International. 2008; 13(3):209-23. https://doi.org/10.1108/13620430810870476

15. The drivers of employee engagement. Available from: https://www.employment-studies.co.uk/system/files/ resources/files/408.pdf. Date accessed: 2004.

16. Little B, Little P. Employee engagement: Conceptual issues. Journal of Organizational Culture, Communications and Conflict. 2006; 10(1):111-20.

17. Harter JK, Schmidt FL, Hayes TL. Business-unit-level relationship between employee satisfaction, employee engagement, and business outcomes: A meta-analysis. Journal of Applied Psychology. 2002; 87(2):268-79. https:// doi.org/10.1037//0021-9010.87.2.268 PMid:12002955

18. Wefald AJ, Downey RG. Construct dimensionality of engagement and its relationship with satisfaction. The Journal of Psychology. 2009; 143(1):91-112. https://doi. org/10.3200/JRLP.143.1.91-112 PMid:19157075

19. Giallonardo LM, Wong CA, Iwasiw CL. Authentic leadership of preceptors: predictor of new graduate nurses' work engagement and job satisfaction. Journal of Nursing Management. 2010; 18(8):993-1003. https://doi. org/10.1111/j.1365-2834.2010.01126.x PMid:21073571

20. Rich BL, Lepine JA, Crawford ER. Job engagement: Antecedents and effects on job performance. Academy of Management Journal. 2010; 53(3):617-35. https://doi. org/10.5465/amj.2010.51468988
21. Kataria A, Garg P, Rastogi R. Employee Engagement and Organizational Effectiveness: The Role of Organizational Citizenship Behavior. International Journal of Business Insights \& Transformation. 2012; 6(1):102-13.

22. Ariani DW. The relationship between employee engagement, organizational citizenship behavior, and counter productive work behavior. International Journal of Business Administration. 2013; 4(2):46-50. https://doi. org/10.5430/ijba.v4n2p46

23. Albdour AA, Altarawneh II. Employee engagement and organizational commitment: Evidence from Jordan. International Journal of Business. 2014; 19(2):192-200.

24. Job engagement: Construct validation and relationships with job satisfaction, job involvement, and intrinsic motivation. Available from: http://ufdc.ufl.edu/UFE0015674/00001. Date accessed: 2006.

25. Hakanen JJ, Perhoniemi R, Toppinen-Tanner S. Positive gain spirals at work: From job resources to work engagement, personal initiative and work-unit innovativeness. Journal of Vocational Behavior. 2008; 73(1):78-91. https://doi. org/10.1016/j.jvb.2008.01.003

26. Bakker AB, DemeroutiE. The job demands-resources model: State of the art. Journal of Managerial Psychology. 2007; 22(3):309-28. https://doi.org/10.1108/02683940710733115

27. Schaufeli W, Salanova M. Work engagement: An emerging psychological concept and its implications for organizations. Research in social issues in management. Managing Social and Ethical Issues in Organizations. 2007; p. 135-77.

28. Hobfoll SE, Johnson RJ, Ennis N. Resource loss, resource gain, and emotional outcomes among inner city women. Journal of Personality and Social Psychology. 2003; 84(3):632-40. https://doi.org/10.1037//0022-3514.84.3.632 PMid:12635922

29. Xanthopoulou D, Bakker AB, Demerouti E. Work engagement and financial returns: A diary study on the role of job and personal resources. Journal of Occupational and Organizational Psychology. 2009; 82(1):183-200. https:// doi.org/10.1348/096317908X285633

30. Sundaray BK. Employee engagement: a driver of organizational effectiveness. European Journal of Business and Management. 2011; 3(8):53-9.

31. Davila N, Pina-Ramirez W. What Drives Employee Engagement? It's All About the 'I'. Public Manager. 2014; 43(1):6-9.

32. De Cremer D, Mulder LB. A passion for respect: On undersetting the role of human needs \& morality. Gruppendynamik und Organisationsberatung. 2007; 38(4):439-49. https://doi.org/10.1007/s11612-007-0036-1

33. Tyler T, Lind EA. A Relational Model of Authority in Groups. Advances in Experimental Social Psychology. 1992; p. 115-91. https://doi.org/10.1016/S0065-2601(08)60283-X 
34. Van Quaquebeke N, Eckloff T. Defining respectful leadership: What it is, how it can be measured, \& another glimpse at what it is related to. Journal of Business Ethics. 2010; 91(3):343-58. https://doi.org/10.1007/s10551-0090087-Z

35. Van Quaquebeke N, Zenker S, EckloffT. Find out how much it means to me! The importance of interpersonal respect in work values compared to perceived organizational practices. Journal of Business Ethics. 2009; 89(3):423-31. https://doi.org/10.1007/s10551-008-0008-6

36. Half of employees don't feel respected by their bosses. Available from: https://hbr.org/2014/11/half-of-employeesdont-feel-respected-by-their-bosses. Date accessed: 19/11/2014.

37. Dillon RS. Respect: A philosophical perspective. Gruppendynamik und Organisations Beratung. 2007; 38(2):201-12. https://doi.org/10.1007/s11612-007-0016-5

38. Ramarajan L, Barsade SG, Burak O. The influence of organizational respect on emotional exhaustion in the human services. The Journal of Positive Psychology. 2008; 3(1):4-18. https://doi.org/10.1080/17439760701750980

39. Rogers KM, Ashforth BE. Respect in organizations: Feeling valued as "we" \& "me". Journal of Management. 2017; 43(5):1578-608. https://doi.org/10.1177/0149206314557159

40. Spears R, Ellemers N, Doosje B. The Individual within the Group: Respect! Individuality and the Group: Advances in Social Identity. 2006; p. 176-95. https://doi. org/10.4135/9781446211946.n10

41. Respectful Manager: Cracking the Code for Good Management. Available from: https://www.ebay.com/p/ The-Respectful-Manager-Cracking-the-Code-for-GoodManagement-by-Terry-A-Sheridan-2018-Hardcover/2405 50544?iid=132943740137. Date accessed: 2018.

42. The great workplace: how to build it, how to keep it, and why it matters. Available from: https://www.amazon. com/Great-Workplace-Build-Keep-Matters-ebook/dp/ B004EEOJVY. Date accessed: 23/11/2010.

43. De Cremer D, Tyler TR. Am I respected or not?: Inclusion \& reputation as issues in group membership. Social Justice Research. 2005; 18(2):121-53. https://doi.org/10.1007/ s11211-005-7366-3

44. Huo YJ, Binning KR. Why the psychological experience of respect matters in group life: An integrative account. Social \& Personality Psychology Compass. 2008; 2(4):1570-85. https://doi.org/10.1111/j.1751-9004.2008.00129.x

45. Nembhard IM, Edmondson AC. Making it safe: The effects of leader inclusiveness \& professional status on psychological safety \& improvement efforts in health care teams. Journal of Organizational Behavior. 2006; 27(7):94166. https://doi.org/10.1002/job.413
46. Psychological Safety. Available from: https://en.wikipedia. org/wiki/Psychological_safety. Date accessed: 03/04/2019.

47. Carmeli A, Gittell JH. High-quality relationships, psychological safety, \& learning from failures in work organizations. Journal of Organizational Behavior. 2009; 30(6):709-29. https://doi.org/10.1002/job.565

48. Lester SW, Brower HH. In the eyes of the beholder: The relationship between subordinates' felt trustworthiness \& their work attitudes \& behaviors. Journal of Leadership \& Organizational Studies. 2003; 10(2):17-33. https://doi. org/10.1177/107179190301000203

49. Want Your Employees to Trust You? Show You Trust Them. Available from: https://hbr.org/2017/07/wantyour-employees-to-trust-you-show-you-trust-them. Date accessed: 05/07/2017.

50. Brower HH, Lester SW, Korsgaard MA. A closer look at trust between managers \& subordinates: Understanding the effects of both trusting \& being trusted on subordinate outcomes. Journal of Management. 2009; 35(2):327-47 https://doi.org/10.1177/0149206307312511

51. Dirks KT, Ferrin DL. Trust in leadership: Meta-analytic findings and implications for research and practice. Journal of Applied Psychology. 2002; 87(4):611-28. https://doi. org/10.1037//0021-9010.87.4.611 PMid:12184567

52. Salamon SD, Robinson SL. Trust that binds: the impact of collective felt trust on organizational performance. Journal of Applied Psychology. 2008; 93(3):593-600. https://doi. org/10.1037/0021-9010.93.3.593 PMid:18457488

53. Seppala T, Lipponen J, Pirttila-Backman AM. A TrustFocused Model of Leaders' Fairness Enactment. Journal of Personnel Psychology. 2012; 11(1):20-30. https://doi. org/10.1027/1866-5888/a000057

54. Bernstrom VH, Svare H. Significance of Monitoring and Control for Employees' Felt Trust, Motivation, and Mastery. Nordic Journal of Working Life Studies. 2017; 7(4):29-49. https://doi.org/10.18291/njwls.v7i4.102356

55. Wrzesniewsky A, Dutton JE. Crafting A job: Revisionning Employees as Active Crafters of Their Work. Academy of Managment Review. 2001; 26:179-201. https://doi. org/10.5465/amr.2001.4378011

56. Deng J, Wang KY. Feeling trusted and loyalty: Modeling supervisor-subordinate interaction from a trustee perspective. International Employment Relations Review. 2009; 15(1):16-38.

57. Barth AL, de Beer W. People-Focused: Respect and Trust. In Performance Management Success. 2018; p. 89-100. https://doi.org/10.1007/978-3-319-64936-8_9

58. Laschinger HKS, Finegan J. Using empowerment to build trust and respect in the workplace: A strategy for addressing the nursing shortage. Nursing Economics. 2005; 23(1):6-12. 
59. Lau DC, Liu J, Fu PP. Feeling trusted by business leaders in China: Antecedents and the mediating role of value congruence. Asia Pacific Journal of Management. 2007; 24(3):321-40. https://doi.org/10.1007/s10490-006-9026-Z

60. Antoniazzi CD. Respect as experienced by registered nurses. Western Journal of Nursing Research. 2011; 33(6):745-66. https://doi.org/10.1177/0193945910376516 PMid:20647549

61. Tyler TR, Blader SL. he group engagement model: Procedural justice, social identity, \& cooperative behavior. Personality \& Social Psychology Review. 2003; 7(4):34961. https://doi.org/10.1207/S15327957PSPR0704_07 PMid:14633471

62. Greenberg J. Organizational justice: Yesterday, today, and tomorrow. Journal of Management. 1990; 16(2):339-432. https://doi.org/10.1177/014920639001600208

63. Colquitt JA, Conlon DE, Wesson MJ, et al. Justice at the millennium: A meta-analytic review of 25 years of organizational justice research. Journal of Applied Psychology. 2001; 86(3):425-45. https://doi. org/10.1037/0021-9010.86.3.425 PMid:11419803

64. Cohen-Charash Y, Spector PE. The role of justice in organizations: A meta-analysis. Organizational Behavior \& Human Decision Processes. 2001; 86(2):278-321. https:// doi.org/10.1006/obhd.2001.2958

65. Greenberg J. The Social Side of Fairness: Interpersonal and Informational Classes of Organizational Justice. Justice in the Workplace: Approaching Fairness in Human Resource Management. 1993; p. 79-103.

66. Colquitt JA. On the dimensionality of organizational justice: a construct validation of a measure. Journal of Applied Psychology. 2001; 86(3):386-95. https://doi. org/10.1037//0021-9010.86.3.386 PMid:11419799

67. Organizational justice and human resource management. Available from: https://us.sagepub.com/en-us/nam/ organizational-justice-and-human-resource-management/ book5737. Date accessed: 1998.

68. Saks AM. Antecedents and consequences of employee engagement. Journal of Managerial Psychology. 2006; 21(7):600-19. https://doi.org/10.1108/02683940610690169

69. Nadiri H, Tanova C. An investigation of the role of justice in turnover intentions, job satisfaction, and organizational citizenship behavior in hospitality industry. International Journal of Hospitality Management. 2010; 29:33-41. https:// doi.org/10.1016/j.ijhm.2009.05.001

70. Demir M. Effects of organizational justice, trust \& commitment on employees' deviant behavior. Anatolia. 2011; 22(2):204-21. https://doi.org/10.1080/13032917.2011 .597934

71. Fuller JB, Hester K, Barnett T. Perceived external prestige \& internal respect: New insights into the organizational identification process. Human Relations. 2006; 59(6):81546. https://doi.org/10.1177/0018726706067148

72. Brower HH, Schoorman FD, Tan HH. A model of relational leadership: The integration of trust \& leader-member exchange. The Leadership Quarterly. 2000; 11(2):227-50. https://doi.org/10.1016/S1048-9843(00)00040-0

73. McAllister DJ. Affect-\& cognition-based trust as foundations for interpersonal cooperation in organizations. Academy of Management Journal. 1995; 38(1):24-59. https://doi.org/10.2307/256727

74. Conway JM, Huffcutt AI. A Review and Evaluation of Exploratory Factor Analysis Practices in Organizational Research. Organizational Research Methods. 2003; 6(2):147-68. https://doi.org/10.1177/1094428103251541

75. Hu LT, Bentler PM. Cutoff criteria for fit indexes in covariance structure analysis: Conventional criteria versus new alternatives. Structural Equation Modeling: A Multidisciplinary Journal. 1999; 6(1):1-55. https://doi. org/10.1080/10705519909540118

76. Lowry PB, Gaskin J. Partial Least Squares (PLS) Structural Equation Modeling (SEM) for Building and Testing Behavioral Causal Theory: When to Choose It and How to Use It. IEEE Transactions on Professional Communication. 2014; $\quad$ 57(2):123-46. https://doi.org/10.1109/ TPC.2014.2312452

77. Gaskin J, Lim J. Master Validity Tool. AMOS Plugin. 2016; p. 1-12.

78. Hassan A, Jubari IHAA. Organizational justice \& employee work engagement: LMX as mediator. Journal for International Business \& Entrepreneurship Development. 2010; 5(2):167-78. https://doi.org/10.1504/ JIBED.2010.037000

79. Kramer RM. Divergent realities and Convergent Disappointments. Trust in organizations: Frontiers of Theory and Research. 1996; p. 216-45.

80. Burke CS, Sims DE, Lazzara EH. Trust in leadership: A multi-level review and integration. The Leadership Auarterly. 2007; 18(6):606-32. https://doi.org/10.1016/j. leaqua.2007.09.006

81. Laschinger HKS. Hospital nurses'; perceptions of respect and organizational justice. Journal of Nursing Administration. 2004; 34(7-8):354-64. https://doi.org/10.1097/00005110200407000-00009

82. Ambrose ML, Schminke M. Organization structure as a moderator of the relationship between procedural justice, interactional justice, perceived organizational support, and supervisory trust. Journal of Applied Psychology. 2003; 88(2):295-300. https://doi.org/10.1037/0021-9010.88.2.295 PMid:12731713

83. Barling J, Phillips M. Interactional, formal, and distributive justice in the workplace: An exploratory study. The Journal 
of Psychology. 1993; 127(6):649-56. https://doi.org/10.1080 /00223980.1993.9914904

84. Banerjee R, Banerjee S. A study of perceived organizational justice, trust and organizational citizenship behaviour. IOSR Journal of Business and Management. 2013; 12(4):3643. https://doi.org/10.9790/487X-1243643

85. Aryee S, Budhwar PS, Chen ZX. Trust as a mediator of the relationship between organizational justice \& work outcomes: Test of a social exchange model. Journal of Organizational Behavior. 2002; 23(3):267-85. https://doi. org/10.1002/job.138

86. Podsakoff PM, MacKenzie SB, Lee JY. Common method biases in behavioral research: A critical review of the literature and recommended remedies. Journal of
Applied Psychology. 2003; 88(5):879-89. https://doi. org/10.1037/0021-9010.88.5.879 PMid:14516251

87. Yang J, Mossholder KW. Examining the effects of trust in leaders: A bases- $\&$-foci approach. The Leadership Quarterly. 2010; 21(1):50-63. https://doi.org/10.1016/j. leaqua.2009.10.004

88. Kim TY, Wang J, Chen J. Mutual Trust Between Leader and Subordinate and Employee Outcomes. Journal of Business Ethics. 2018; 149(4):945-58. https://doi.org/10.1007/ s10551-016-3093-y

89. Schoorman FD, Mayer RC, Davis JH. An integrative model of organizational trust: Past, present, \& future. Academy of Management Review. 2007; 32(2):344-54. https://doi. org/10.5465/amr.2007.24348410 